\title{
THE PREDICTABILITY OF ENGLISH READING SKILL FROM INDONESIAN READING SKILL AND ENGLISH KNOWLEDGE AT STUDENTS OF SMAN 1 PADEMAWU-PAMEKASAN
}

\author{
Muflihatun Haqiqiyah \\ STAI Miftahul Ulum Pamekasan \\ E-mail: muflihatunhaqiqiyah@gmail.com
}

\begin{abstract}
The basic problem wants to discuss is: Do Indonesian reading skill and English knowledge correlate with English reading skill at students of SMAN 1 Pademawu? The purpose of the research is find the correlation between Indonesian reading skill and English knowledge on English reading skill at students of SMAN 1 Pademawu. The research gave some useful information about students' Indonesian reading skill and English knowledge on English reading skill. This research also presented the description and the correlation between students' Indonesian reading skill and English knowledge on English reading skill. The technique of collecting data was by using a test. After the data of the students' Indonesian reading tests and English knowledge tests and English reading tests collected, the data was statistically computed (SPSS 17.00) to find out the correlation between the two variables. From the tests, it was found out there was not a significant correlation with students' Indonesian reading skill and English knowledge on English reading skill. It is suggested that to have a good capability in English reading skill, students should have a good ability in Indonesian reading skill and English knowledge.
\end{abstract}

Keywords: Indonesian Reading skill, nglish Reading skill, English Knowledge 


\begin{abstract}
ABSTRAK
Masalah utama yang ingin di diskusikan adalah, apakah kemampuan membaca bahasa Indonesia dan pengetahuan bahasa inggris berhubungan dengan kemampuan membaca bahasa inggris di SMAN 1 Pademawu? Tujuan dari penelitian ini adalah menemukan hubungan antara kemampuan membaca bahasa Indonesia dan pengetahuan bahasa Inggris dalam kemampuan membaca bahasa Inggris pada siswa SMAN 1 Pademawu?. Penelitian ini memberikan beberapa informasi yang berguna tentang kemampuan membaca bahasa Indonesia dan pengetahuan bahasa Inggris terhadap kemampuan membaca bahasa Inggris. Penelitian ini juga menyajikan gambaran dan hubungan terhadap kemampuan membaca bahasa Indonesia dan pengetahuan bahsa Inggris terhadap kemampuan membaca bahasa Inggris. Teknik pengumpulan data adalah dengan menggunakan tes. Setelah data dikumpulkan, data akan dihitung secara statistic dengan system penghitungan (SPSS 17.00) untuk menemukan hubungan antara kedua variabel. Dari beberapa tes, ditemukan bahwa tidak ada hubungan yang signifikan anatara kemampuan membaca bahasa Indonesia dan pengetahuan bahsa Inggris terhadap kemampuan membaca bahasa Inggris. Disarankan untuk memiliki kemampuan yang baik dalam kemampuan membaca bahasa Inggris, maka siswa harus memiliki kemampuan membaca bahasa Indonesia dan pengerahuan bahasa Inggris pula.
\end{abstract}

Kata kunci: Indonesian Reading skill, English Reading skill, English Knowledge

\title{
A. INTRODUCTION
}

Reading is the system in comprehending some ideas that is delivered by the author to the reader. We can find descriptions in the writers' language with our own language. Reading is also the capability in transferring few information to another people through sentences or images that written in form of books or papers. Reading is also the one of ability that should have by teachers to make students get what the 
writers want to say to the readers. ${ }^{1}$

The most important thing in applying first language (L1) from second language (L2) learning is the proficiency L2 learners, especially adults. L2 learners must have reached level of fluency in L1. ${ }^{2}$ Learners who learned first and second language performance are related to another learners are captured and attended by communities of second or foreign language teaching for years. ${ }^{3}$ In other hands, in improving language learners can facilitate L2 reading performance by the extent of L1 reading ability. ${ }^{4}$

Vocabularies, grammar and sentence structure become requirements in second language reading. Learners who has low level can read textbook from the writer and students who has upper level can develop their ability in reading the texts. Sometimes, L2 students may not understand grammar. Some ideas get by the students who has high level and ability in comprehending the texts.

The studies have investigated whether there was or not correlation between Indonesian reading skill and English knowledge on English reading skill at SMAN 1 Pademawu. ${ }^{5}$ The limited research on the Indonesian reading tests focuses on students' ability in understanding the text given. English knowledge tests focused on the students' ability in answering items related with grammar and vocabulary. And English reading tests focused on student's ability in comprehending English passage and answering the questions related with the text.

\section{B. THEORETICAL FRAMEWORK}

The concept of L1 and L2 Reading

\footnotetext{
${ }^{1}$ D Brown, "Teaching by Principles: An Interactive Approach to Language Pedagogy . Addison Wesely Longman," Inc. USA, 2001.

${ }^{2}$ Correlli Barnett, The audit of war: the illusion and reality of Britain as a great nation (Macmillan, 1986).

${ }^{3}$ Thomas A Upton dan Li-Chun Lee-Thompson, "The role of the first language in second language reading," Studies in second language acquisition, 2001, 469-95.

${ }^{4}$ Michael Pressley et al., "How does Bennett Woods Elementary School produce such high reading and writing achievement?," Journal of Educational Psychology 99, no. 2 (2007): 221.

5 Muflihatun Haqiqiyah, "Islamisasi Dan Konservasi Keagamaan Masyarakat Madura," eduthink: Jurnal Pendidikan Islam 1, no. 1 (2019): 49-71.
} 
Grabe states reading in second language is the capability in correlating second language and first language into a dual-language processing system. Many items in understanding first language and second language reading, and motivate students support in reading if they are reading in their L1 or their L2. There are: ${ }^{6}$

1. Lexical and meaning characteristics

Nagy in Grabe, says the earlier capability of L2 readers in beginning to read, do not match their L1 beginner. The vocabularies should be belonged by L2 learners for about 5,000 to 8,000 words as high learners. It supposed to give motivation in some types to in reading L2 passage.

2. Developmental and educational differences in L1-L2 reading Readers should have high motivation in learning language from L1 to $\mathrm{L} 2$ readers. In many contexts around the world, reading texts that often are very complicated and at the upper edge of their linguistic resources. L2 reading goals for students is constraint limited expectation of goal and are also constrained by the limited expectations of other terms of outcome goals and purposes for reading.

3. Key sociocultural and institutional factors in $\mathrm{L} 1-\mathrm{L} 2$ reading L2 reading skill is influenced by the ability in learning other languages besides first language. Some of people are able to get second language cause of he/she has good knowledge about a language so they can be easily in learning another word. In some cultures, texts are everywhere. They are on flyers, on advertisements, in doctors' offices, in most homes, in all schools, on easily accessible and widespread internet sites. In other cultures, texts may not pervasively saturate the environment. Cultural and society is covered by the reader in these types and the uses of texts used. Particularly, the role of texts is different for L1 and L2 reader as a foreign language. ${ }^{7}$

${ }^{6}$ GRABE William, Reading in a Second Language: Moving from Theory to Practice (Cambridge University Press, New York, 2009). P.129

7 Moh Suyudi, Muhammad Muhlis, dan Mansur Mansur, "Pesantren Sebagai Pusat Sertifikasi Dan Edukasi Sumber Daya Insani Pariwisata Syariah Dalam Penguatan Industri Halal Di Indonesia," Dinar: Jurnal Ekonomi dan Keuangan Islam 6, no. 2 (2019): 135-45. 
Grabe says that the impact of text organization and genre variability on L2 reading can be considerable. Texts that $\mathrm{L} 2$ students read can be organized in ways that seem unusual, disorganized, ineffective, and even hard to understand. ${ }^{8}$

It can be concluded that students feel difficulty in comprehending the text because of they lack of new vocabularies. Word recognition in the text is very important for students. In reading comprehension Learners should have many words to be a good reader.

Grabe defines that readers need motivation in reading L2often have different motivation when compared with reading in their L1s. In fact, one can say that every person will have unique combination of motivations in reading whether in the L1 or the L2. In many L1 settings, people read because they have certain types of expertise or skills that they are willing to develop, or they read for enjoyment, often reading for hours or exploring Web pages for extended periods of time. L2 reading goals for students are often constrained by the limited expectations of others in terms of outcome goals and purposes for reading.

Hence, motivation is also important for students. Many scientists argue that motivation is a support comes from ourselves to comprehend contents what we read in the texts. We can apply reading effectively when we have high motivation. It can increase our interest in reading ability. It means that in L2 and L1 reading can be comprehended such as a correspondent in $\mathrm{L} 1$ reading between people who has lower skilled and high skilled readers. Lower skilled words.

\section{TYPES OF READING}

Ambatchew, M D states that reading is the way how to student combines a text and meanings of the text, which is some approaches can be presented by the teacher or scientist. ${ }^{9}$

It can be concluded in reading; written text are combined with students. It can relating interaction not only to the students but also interpreting ideas in order to comprehend the reality in order to

\footnotetext{
${ }^{8}$ William, Reading in a Second Language: Moving from Theory to Practice.P.133

${ }^{9}$ Michael Daniel Ambatchew, "The effect of primary English readers on reading skills in Ethiopia," Unpublished Dissertation, University of Pretoria etd, 2003.
} 
understand the facts and obtain some ideas from the text.

1. Read Aloud

Barrentine in Tompkins states that in contributing the alternative selection for students mistakes is using interactive read aloud and doing little practice for a child and group. It can be a bridge between reader and listeners get a good message from the texts. ${ }^{10}$

2. Shared Reading

Tompkins also defines that it has similarity with Reading Aloud. The instructor takes a text to the pupil, but in this part the story is still read by the teacher. In some reasons, the text such as a big book or multiple copies should be able to seen by the students easily.

It can be concluded, that the student needs book once a day or two before. Reading a book in a good shared reading. In turn reading ability is become the needs. A good environment is required for the pupils to make them more comprehend about reading passage.

3. Guided Reading

Tompkins argues that it is a form of responsibility to make students capable in reading strategies. The prompts and reinforcement are offered to the students, the text can be read by the students silently or softly because it can help the student to become economies reader.

The teacher asks a student to read a part of text loudly and he/she offers help to the students who has difficulty and look them how the students are holding the tasks. Mini lesson can be used as a plan to teach them as a little part of the story which is new to the students. In reading strategies teacher should instruct students' reading. Little group students is carried by students who has the same level in guided reading.

4. Fluency Reading

a. In this part, students' comprehension can be increased through fluency in the activity. Some approaches like skimming, scanning and identifying main ideas can make students' fluency increased.

b. Choral reading: type of reading aloud where the students read a

${ }^{10}$ Gail E Tompkins, Language arts essentials (Prentice Hall, 2006).P.133 
text with the peers. For instance, students can get ideas from the song or passages by the teachers given fluently.

c. Timed readings: the teacher gives time to students to read a texts. Teachers takes part in assessing the students. Then, the teacher counts how many words can be read by the students in comprehending the texts and give a good score to them.

d. Buddy reading: the ability in all aspects of the students in reading a passage becomes the major assessment.

e. Modeled reading: the tutor becomes a model when he/she reads a story and the students also read what the teacher says. Finally, the teacher assess them.

5. Independent Reading

Taylor as quoted in Tompkins argues that accuracy is the important thing assess reading students' ability. Students' motivation is emphasized because students asked to give their opinions to another students in the class. Teacher can help them to take a suitable book for each students'. Discussion with the other students' can be a factor in changing some ideas he/she gets.

\section{FACTORS AFFECTING READING ABILITY}

Torgesen and colleagues in Thomas McClure (2008) identified six critical factors in reading ability as below. ${ }^{11}$

1. Fluency

The capability in reading strategies who the readers should be fluent in reading a text. Some students are not able to make a conclusion from the story because the limitation of their knowledge include vocabularies, grammar and how to pronounce words well. It can cause the students' fail in getting information from the story. It is very important to understand the items in reading skills.

2. Vocabulary:

It is the important thing when the student must read the story. The way how to change word to word becomes a sentence should be understood by the students. In comprehending second language,

${ }^{11}$ Carla Thomas McClure, "The benefits of teacher collaboration," District Administration 44, no. 10 (2008): 82-83. 
students must memorize hundreds words as beginning readers. Each readers has difficulty itself in receiving ideas, because different people has different sides in reading activities.

Grabe also argues that when we learn some words in the story, we have to comprehend what the writer wants to say. So, vocabulary becomes the first thing should be given in reading ability. In other words, without vocabulary we cannot read effectively and understanding the contents of passage. ${ }^{12}$

3. Background or prior knowledge related to the content of the text being read

Grabe states that knowledge about grammar, vocabularies are some factor in reading comprehension process, the role of knowledge in reading is more complex than, these demonstration might suggest, and the methods in which background knowledge has different view in reading skill although background knowledge become one of unseparated thing in reading comprehension, nor can it be viewed as a simple, uniformly positive factor. Weaker readers often call up the wrong knowledge and draw wrong inferences.

In admitting the complexities of background knowledge, it is first important to make knowledge be great point in studying second language especially social background of people and how people take their daily. Second, there are many situations in which every person comprehend texts in getting new knowledge when we do not know their self-esteem. Third, knowledge involves motivations, attitudes, goals and language proficiency must be applied by someone who wants to learn a good language better than before. Fourth, the usage of knowledge in cognitive treatments through reading comprehension. Fifth, in measuring social background in comprehension activity, knowledge is one of factors to be determined.

4. Active and flexible use of reading strategies

Breznitz in Grabe says that reading has two ways in interactive process. Cognitive activity can be combined with discussing together in the class at the same time. When the reader and the writer take and give some messages from the story given, it is called reading. The

${ }^{12}$ William, Reading in a Second Language: Moving from Theory to Practice. 
ways how to understand and present the texts also get information that the author wants.

It means that social background be the readers also bring a wide range of background knowledge to reading, and she or he actively constructs the meaning if the text by comprehending what the writer intends and by interpreting it in terms of the background knowledge activated by the reader.

Grabe defines that reading is also flexible process. As reader purpose shifts, as comprehension is impeded, or as interest varies, the reader adjusts reading processes and goals. The flexibility demonstrated by fluent readers keeps the processes aligned with each other.

It means that reading can be defined as transmitting process an idea between the author and the reader. The purpose of students do not get the comprehension of text because they do not have sufficient vocabularies in performing reading tasks.

5. Higher level reasoning and thinking skills

According to Jacobs in King.et al argued that students' awareness is important in their thinking processes, the choices in playing a role can be realized by the situation. To decide reading process, the needs of culture, experience, preferences, desires, interest and passions can radically.

According to Lewis and Smith tells, a person can take new information to reach the purpose of reading by higher order thinking where the readers can create new information, a new object and make new description and for non-routine problem can be found the best solution. ${ }^{13}$

It means that students are believed to find new ideas without cares of something they got because the goal is to make the reader be able to carry new information from the text without any doubts. It is called skepticism.

6. Motivation and engagement for understanding and learning from a

\footnotetext{
${ }^{13}$ Lewis J Smith, Michael Houston, dan James Anderson, "Increased levels of glutathione in bronchoalveolar lavage fluid from patients with asthma," American Review of Respiratory Disease 147 (1993): 1461.
} 
text

In motivating students to read a book, teachers should perform what they do in daily life. It can make the students be attractive in doing the same thing like they do. ${ }^{14}$ Then, teacher can make a discussion about what the students do too. ${ }^{15}$

It means, motivation develops when each students' experiences control over the processes and tasks that lead to successful outcomes and each of them can perform their experience individually with another comprehension without changing the contents of text.

\section{E. GRAMMAR}

According to Uluogulu that all of skills in learning second language has the requirements. They have to understand the grammar and also knowing the meaning of words that they read in English textbooks. Teacher should instruct students to understand about the role of knowledge. ${ }^{16}$

There are some differences about declarative knowledge and procedural knowledge. Declarative knowledge supposed to comprehend something to be performed. It this part, the students' knowledge should be emphasized.

Procedural knowledge is how students can follow the instruction in making something based on their own words.

In this method, students are asked to communicate what they get o another people accurately. Sometimes, the accuracy of using grammar is not observed by the speaker. Both of them can increase students' ability in reading and speaking. Some strategies can be applied students and teachers in the class. They are:

1. Relate knowledge needs to learning goals.

The using of vocabulary and grammar is defined by teachers in order to students can be brave in expressing what students know about

\footnotetext{
${ }^{14}$ Riyad Karmy-Jones et al., "Practice patterns and outcomes of retrievable vena cava filters in trauma patients: an AAST multicenter study," Journal of Trauma and Acute Care Surgery 62, no. 1 (2007): 17-25.

${ }^{15}$ Pressley et al., "How does Bennett Woods Elementary School produce such high reading and writing achievement?"

${ }^{16}$ Belkis Uluoğlu, "Design knowledge communicated in studio critiques," Design Studies 21, no. 1 (2000): 33-58.
} 
the text. Not only procedural knowledge but also declarative knowledge, grammar is so important in learning second language. Many students do not have enough knowledge in reading and speaking, it can cause the last goal of learn L2 is not better than student who has more knowledge. The comprehension in reading and speaking is make the listener understand what the writer wants to deliver. It comes from students who wants to learn simple items grammatically.

2. Provide plentiful, appropriate language input.

It is not easy in understanding second language for students who wants to learn instantly. They need long period in learning grammar, changing the words to sentences and speaking in front of another people. They should comprehend all of aspect in background knowledge appropriately. Type of contexts in some texts contains some keywords that can be understood by the reader. When the students can find its keywords, of course they can catch what the writer wants.

3. Use predicting skills.

In communication types, some features like structure can give a contribution to students. The existence of structure can help students in studying oral or written text. Teacher gives a history textbook and article, then asked them to make a conclusion or ask them to retell using their own words from tasks given. At the end, teacher can compare how students are capable in reviewing the text grammatically. Although there are differences in presenting history textbooks and newspaper articles at contents side. The history books more complete than newspaper article in some features such as the using of complex sentences.

A newspaper article is dominated by tenses that enables students only discuss what the contents of its. The students cannot predict what teacher wants whether the task is not complete. The demonstration of Douglas and Biber argued that some linguistic features can cause some impacts to different communication

4. Limit expectations for drills.

a. The involvement of pronouns for nouns, tense of verbs, number 
can make students easier to remind some words like regular or irregular verbs

b. In writing, students can be taken tasks like text which has separated forms in meaning and use

c. Most of students say" We don't like grammar". It is caused by students who cannot study grammar material accurately. In grammar, students are asked to do all patterns that teacher taught. Students' accuracy become the most important thing.

5. Teaching Reading

The purpose of reading is to know a language literally. While students are learning materials, means they can bring a knowledge. From students' knowledge, students can apply their culture, what their environment likes and it will be appeared higher or lower students in comprehending a language.

In learning a language, students are asked to learn in using its vocabulary, grammar, and sentence structure. Student who has high and low level in getting the textbooks. Low level student only focuses in reading sentences and paragraphs only, but high level students can learn and develop a language from the great authors.

In this part, students are given a freedom in communicating what they want say. All types of texts can be used in the classroom. As long as the students want to express their ideas they got. For example, travel and tourism web sites, newspaper articles can become appropriate material for every students' level as the objective of reading in communicative approach. In language classroom, practice is an important thing to teach a language especially in reading ability.

\section{F. METHOD OF STUDY}

This research uses descriptive quantitative research design, and the writer intends to the correlation between students' Indonesian reading skill and English knowledge correlate with English reading skill. The procedures of this research were as follows: 1). Testing the validity (difficulty level and discriminating power) and reliability 2). Analyzing aspects Indonesian reading test, English knowledge tests and English reading tests. 3). Data collection 4). Data analysis

The instrument uses in this research is test. The type of the 
instrument uses in this research is an objective test. The test is divided into three categories those are Indonesian reading tests, English knowledge tests and English reading test.

In this study, the writer used an objective test to get the score of the students' ability in Indonesian reading test, English knowledge tests and English reading test. Each test must have relevancy with the research variables especially the indicators. The test is divided into three parts; the first is Indonesian reading test which consists of 27 items. The second is English knowledge test which consists of 35 items.

The third is English reading test which consists of 23 items. The material: Indonesian reading text (1. Reading text and finding moral value based on the text given ). (2. English knowledge tests) grammar and vocabulary; the use of prepositions, pronouns, conjunctions, and auxiliary verb, matching the word with its definition. The test is taken from the Gudang soal grammar and LKS). All the tests conducted in multiple choice items.

In testing validity, the research used difficulty level and used the following formula:

$P=\frac{A}{N} \times 100 \%$

Where:

$P=$ difficulty index of item

$A=$ Number of correct answers to item

$N=$ Number of sample

For discriminating power, the researcher used the following interpretation:

The interpretation of DP (Discrimination Power) value

\begin{tabular}{|l|l|l|}
\hline DP $=$ & Quality & Recommendations \\
\hline$>0,39$ & Very Good & Accepted \\
\hline $0,30-0,39$ & Good & Accepted \\
\hline $0,20-0,29$ & Moderate & Accepted \\
\hline $0,01-0,19$ & Poor & Discarded \\
\hline$<-0,00$ & Very poor & Discarded \\
\hline
\end{tabular}


In reliability, the researcher used the following interpretation:

The interpretation of the r-value

\begin{tabular}{|l|l|l|}
\hline No & The r-value & Category \\
\hline 1 & $0,800-1000$ & Very high \\
\hline 2 & $0,600-0,799$ & High \\
\hline 3 & $0,400-0,599$ & Satisfactory \\
\hline 4 & $0,200-0,399$ & Low \\
\hline 5 & $0,000-0,199$ & Very low \\
\hline
\end{tabular}

To measure the reliability of the test, she computes by using the following formula (Heaton, 1986: 164)

$\mathrm{RI}=\frac{K}{K-1}\left(1-\frac{m(K-m}{K S^{2}}\right)$

$\mathrm{RI}=$ Reliability

$\mathrm{K}=$ Number of items in test

$\mathrm{M}=$ Mean

$\mathrm{S}=$ standard deviation

\section{G. RESULT OF THE STUDY}

Based on descriptive statistics mean of Indonesian reading is 15.65 and standard deviation is 3.346 with the number of sample is 52 people. For English knowledge data descriptive statistics in regression analysis showed that the mean is 20.48 and standard deviation was 4.861 with the same sample. In English reading, its mean is 15.65 and standard deviation is 3.016 .

R- value of Indonesian Reading Skill, English Knowledge and English Reading Skill is 0.129. R-square of the variables is 0.017 or $1.7 \%$. It means that the English reading skill (Y) is simultaneously not influenced by Indonesian reading skill (X1) and English knowledge (X2) to the amount $1.7 \%$.

The result of the correlation analysis as showed that there was not significant correlation between students' ability in Indonesian reading skill and English knowledge on English reading skill because the calculated $F$ value is 0.416 with the significant value of $F_{\text {calculated }}$ is 0.662 or $66 \%$, which is greater than alpha $5 \%(0.05)$. Therefore $\mathrm{H}_{\mathrm{a}}$ is rejected and $\mathrm{H}_{\mathrm{o}}$ is accepted. In conclusion, Indonesian reading skill and English 
knowledge simultaneously do not give significance influence to English reading skill.

\section{H. DISCUSSION}

In this study, the researcher did to test the participants only once. The analysis showed that neither factor was a significant predictor. From the data, analysis in L1 reading ability is analyzed by multiple regression, predictor variables shows L2 knowledge and the criteria variable is L2 reading ability. For the participants, the two factors are accounted for a relatively small proportion of the variety in $\mathrm{L} 2$ reading $\left(\mathrm{R}^{2}=.17, \mathrm{~F}=\right.$ $0,416, P>.05$ ). Neither factor emerged as significant (L2 knowledge: $\beta$ $=.05, \mathrm{t}=.062, \mathrm{p}=1.000 ; \mathrm{L} 1$ Reading: $\beta=.117 ; \mathrm{t}=.912, \mathrm{p}>.05$.

In testing data, she is using validity and reliability. There are 4 validities in testing measure what is supposed. From the four validities, the study uses content validity because the test is used to test students' ability in identifying topic sentence of the paragraph. In analyzing test items, to know the degree of difficulty and discriminating power, the writer uses these procedures: the first, scoring the right answer, the second, deciding the degree of difficulty and discriminating power of each item.

In collecting the data related to students' Indonesian reading skill, the researcher used a set of questions from students' worksheet. It consisted of 27 questions in the form of multiple choices, each item has 5 options and each respondent choose the right answer based on the passage given.

English reading skills were taken from Gudang Soal Reading SMA. There were 23 items in multiple choice forms and has 5 options for each question. Each respondent choose the right answer.

English knowledge is excerpted from Gudang Soal Grammar SMA to assess grammar and vocabulary knowledge. The test was multiple choices form. There were 35 items and the question provided with five options, A, B, C, D and E, and only one is correct.

In analyzed the items, they prepared based on level of difficulty as 
the people's proportion who could answer correctly. The lower of the difficulties has the higher this proportion. In calculating the difficulty of an item, total of number sample is divided by the number of persons who answered it correctly.

Based on the result above, the participants have low level skills. Some factor show reading skills: 1) In word attack skill is as unit of language contains phonemes, syllables and words are represented, 2) In comprehension skill, students are emphasized to understand the contents of text and find the meaning 3) Fluency skills, the readers are assessed accurately and more quickly in reading larger sentences and phrases 4) Critical reading skills, the correlation between cause and effect become an essential part to low level students in first language. Most of whom already have a relatively well-developed oral first language but have had little experience matching the sounds and words of the language to a print representation. This concept reflects the twin processes in reading automatic text recognition versus recoding known oral language through text. In early first language reading, the accuracy and speed worddecoding skill is a strong predictor of comprehension, a stronger predictor than listening comprehension ability. The general comprehension factor is influenced by the differences in reading ability. Students who has low level skill can be practiced and monitored by the teacher using visual perception and phonic analysis.

Grabe said that social influences on literacy development cover a wide spectrum of factors. These factors may reflect the types of students being considered: the likely influences of social, cultural, and institutional backgrounds; and the attitudes of people who impact children's literacy development. Major social factors include the socioeconomic status of the parents and family; the values and attitudes of the family and wider social group; the educational levels of the parents; the patterns of interaction between parents and children; the literacy resources in the home, community, and schools; the uses of language in the home; the training of teachers; and the policies and practices of educational institutions of all types. Finally, teacher should motivate students' learning and their interest in future research. In the end of the research, the study showed that L2 knowledge did not appears as the variable affect in $\mathrm{L} 2$ reading ability. In second language reading 
proficiency, learners need goal syntactic, morphological, and lexical knowledge as treatments. The characteristics of the text and tasks as interactions between one and another. Second language reading comprehension involves the role of syntactic knowledge is pervasive. In linguistic threshold, grammar is the important one in reading comprehension.

There are differences between low frequency and high frequency. One of problem faced is individual's vocabulary knowledge. It is called idiosyncratic. Many different words in many context causes students as inexact indicators for low and high frequency. A second problem is conceptualizing differences in vocabulary knowledge relates to the interaction of vocabulary and world knowledge in conceptualizing differences of vocabulary knowledge. Some meanings incorporate a semantic representation is also involved.

\section{CONCLUSION}

Based on descriptive statistics mean of Indonesian reading is 15.65 and standard deviation is 3.346 with the number of sample is 52 people. For English knowledge data descriptive statistics in regression analysis showed that the mean is 20.48 and standard deviation was 4.861 with the same sample. In English reading, its mean is 15.65 and standard deviation is 3.016. R- value of Indonesian Reading Skill, English Knowledge and English Reading Skill is 0.129. Further analysis of the data found out Fvalue is $0.416(\mathrm{P}<.662)$. Thus, it is concluded that Indonesian reading skill and English knowledge of the eleventh grade students of SMAN 1 Pademawu-Pamekasan do not contribute significantly to their English reading ability.

\section{REFERENCES}

Atkins, Daniel Ewell, John Seely Brown, dan Allen L Hammond. A review of the open educational resources (OER) movement: Achievements, challenges, and new opportunities. Vol. 164. Creative common Mountain View, 2007.

Barnett, Correlli. The audit of war: the illusion and reality of Britain as a 
great nation. Macmillan, 1986.

Bhela, Baljit. "Native language interference in learning a second language:

Exploratory case studies of native language interference with target language usage," 1999.

Haqiqiyah, Muflihatun. "Islamisasi Dan Konservasi Keagamaan Masyarakat

Madura." eduthink: Jurnal Pendidikan Islam 1, no. 1 (2019): 49-71.

Juhari, Juhari, and Zainal Hakim. "INSPIRING TEACHER; Sosok dan

Perannya dalam Mengorganisir Pembelajaran Berbasis Manajemen

Mutu." Al-Insyiroh: Jurnal Studi Keislaman 2.2 (2018): 49-64.

Kahneman, Daniel, Stewart Paul Slovic, Paul Slovic, dan Amos Tversky.

Judgment under uncertainty: Heuristics and biases. Cambridge university press, 1982.

Karmy-Jones, Riyad, Gregory J Jurkovich, George C Velmahos, Thomas Burdick, Konstantinos Spaniolas, Samuel R Todd, Michael McNally, Robert C Jacoby, Daniel Link, dan Randy J Janczyk. "Practice patterns and outcomes of retrievable vena cava filters in trauma patients: an AAST multicenter study." Journal of Trauma and Acute Care Surgery 62, no. 1 (2007): 17-25.

Pressley, Michael, Lindsey Mohan, Lisa M Raphael, dan Lauren Fingeret. "How does Bennett Woods Elementary School produce such high reading and writing achievement?" Journal of Educational Psychology 99, no. 2 (2007): 221.

Ramdhan, Tri Wahyudin. "Model Pengembangan Kurikulum Multikultural." Al-Insyiroh: Jurnal Studi Keislaman 5.2 (2019): 39-53.

Rosszell, Rory H. "Paths to reading fluency-part 2: A review of the effectiveness of timed reading." Global Japanese Studies Review Meiji University 7, no. 1 (2014): 13-28.

Smith, Lewis J, Michael Houston, dan James Anderson. "Increased levels of glutathione in bronchoalveolar lavage fluid from patients with asthma." American Review of Respiratory Disease 147 (1993): 1461.

Suyudi, Moh, Muhammad Muhlis, dan Mansur Mansur. "Pesantren Sebagai

Pusat Sertifikasi Dan Edukasi Sumber Daya Insani Pariwisata Syariah

Dalam Penguatan Industri Halal Di Indonesia.” Dinar: Jurnal Ekonomi dan Keuangan Islam 6, no. 2 (2019): 135-45.

Tompkins, Gail E. Language arts essentials. Prentice Hall, 2006.

Uluoğlu, Belkis. "Design knowledge communicated in studio critiques." 
Design Studies 21, no. 1 (2000): 33-58.

Upton, Thomas A, dan Li-Chun Lee-Thompson. "The role of the first language in second language reading." Studies in second language acquisition, 2001, 469-95.

Vidwans, Mohan P, Susan H Parkinson, Glenn Scott, dan Anthony J Fecteau. "Inertia latching mechanism with floating striker bar." Google Patents, 29 Januari 1991.

William, GRABE. Reading in a Second Language: Moving from Theory to Practice. Cambridge University Press, New York, 2009. 